\title{
Morphological Phylogenetic Analysis of Seven Varieties of Ficus deltoidea Jack from the Malay Peninsula of Malaysia
}

\author{
Hasan N. N. Fatihah ${ }^{1}$, Nashriyah Mat ${ }^{1 *}$, Abdul R. N. Zaimah ${ }^{1}$, Mazlan N. Zuhailah ${ }^{1}$, Haron Norhaslinda ${ }^{1}$, \\ Mahmud Khairil ${ }^{1}$, Abdul Y. Ghani ${ }^{1}$, Abdul M. Ali ${ }^{2}$
}

1 Department of Agricultural Science, Faculty of Agriculture and Biotechnology, Universiti Sultan Zainal Abidin, Gong Badak Campus, Terengganu, Malaysia, 2 Department of Biotechnology, Faculty of Agriculture and Biotechnology, Universiti Sultan Zainal Abidin, Gong Badak Campus, Terengganu, Malaysia

\begin{abstract}
This study is the first report to suggest a morphological phylogenetic framework for the seven varieties of Ficus deltoidea Jack (Ficus: Moraceae) from the Malay Peninsula of Malaysia. Several molecular-based classifications on the genus Ficus had been proposed, but neither had discussed the relationship between seven varieties of $F$. deltoidea to its allies nor within the varieties. The relationship between seven varieties of $F$. deltoidea is still debated due to the extreme morphological variabilities and ambiguous boundaries between taxa. Thus, the correct identification of these varieties is important as several morphological characters are variety-specific. To test the monophyly and further resolved the relationship in F. deltoidea, a morphological phylogenetic analysis was conducted based on herbarium specimens representing the seven varieties of $F$. deltoidea that were collected from the Malay Peninsula of Malaysia, by using related species of the genus Ficus; F. grossularioides, F. ischnopoda and F. oleifolia as the outgroups. Parsimony and neighbour-joining analyses indicated that $F$. deltoidea is monophyletic, in that the seven varieties of $F$. deltoidea nested into two clades; clade subspecies deltoidea (var. deltoidea, var. bilobata, var. angustifolia, var. kunstleri and var. trengganuensis) and clade subspecies motleyana (var. intermedia and var. motleyana).
\end{abstract}

Citation: Fatihah HNN, Mat N, Zaimah ARN, Zuhailah MN, Norhaslinda H, et al. (2012) Morphological Phylogenetic Analysis of Seven Varieties of Ficus deltoidea Jack from the Malay Peninsula of Malaysia. PLoS ONE 7(12): e52441. doi:10.1371/journal.pone.0052441

Editor: Christian Schönbach, Kyushu Institute of Technology, Japan

Received June 23, 2012; Accepted November 13, 2012; Published December 20, 2012

Copyright: (c) 2012 Fatihah et al. This is an open-access article distributed under the terms of the Creative Commons Attribution License, which permits unrestricted use, distribution, and reproduction in any medium, provided the original author and source are credited.

Funding: This study was supported by a Universiti Sultan Zainal Abidin's grant; with a reference number of UDM/09/BR (0013). The funders had no role in study design, data collection and analysis, decision to publish, or preparation of the manuscript.

Competing Interests: The authors have declared that no competing interests exist.

*E-mail: nashriyah@unisza.edu.my

\section{Introduction}

Ficus deltoidea Jack (Ficus: Moraceae) is a diverse species of subgenus Ficus, section Ficus and subsection Frutescentiae [1]; which contains 25-30 species found in the Sino-Himalayan and western Malesian region [2]. Ficus deltoidea is a native and widely distributed throughout Malaysia, Thailand, Sumatra, Java, Kalimantan, Sulawesi and Moluccas [3]. This plant is a small shrub up to $3 \mathrm{~m}$ tall, sometimes occurring as an epiphyte [4]. It can be found in abundance along the beaches, peat soils and in hilly forest up to $3000 \mathrm{~m}$ above sea level [5]. The Malays called F. deltoidea as 'Mas Cotek' due to the presence of golden dots on the upper surface of its lamina [5]. The seven varieties of $F$. deltoidea; namely var. deltoidea, var. bilobata Corner, var. angustifolia (Miq.) Corner, var. intermedia Corner, var. kunstleri (King) Corner, var. motleyana (Miq.) Corner and var. trengganuensis Corner that were found in the Malay Peninsula were described by Kochummen [6]. The plants are often recognized by the presence of golden dots on the upper surface of the lamina, dichotomous midrib, unique fig (syconia) with flowers hidden inside the syconia, leafy twigs and the milky juice [4], [7].

Ficus deltoidea is commonly cultivated as a houseplant for decorative purposes and traditional medicinal uses by the local people [4]. The var. bilobata, var. angustifolia, var. intermedia, var. kunstleri, var. motleyana and var. trengganuensis are commonly used in the Malay traditional medicine [8]. The dried leaves, stems and roots are often commercialized as herbal tea [9]. The decoction of the leaves is traditionally used by women after childbirth to help strengthen the uterus [5]. It is also believed to improve blood circulation, regain energy and enhance fertility naturally for both men and women [10,11]. These claims were supported by previous bioassay studies, demonstrating that the aqueous extract of the leaves contains antidiabetic [12,13] and antinociceptive activities [10]. The leaf extracts were reported to be rich of phenolic and flavonoid compounds which are comparable with black and green teas as well as fruit juices [11]. The flavan-3-ols and flavones were the main compounds that contributed to the total antioxidant activity [11], whereas isovetexin and vetexin were reported to be responsible for the antidiabetic activity [14].

Although $F$. deltoidea has been exploited in many different ways, the taxonomy of this species is still controversial at the varietal level. Historically, several botanical names of $F$. deltoidea have been reported; namely $F$. diversifolia Blume, F. motleyana Miq. and $F$. oleifolia King [4-15]. The extreme morphological variations and unclear boundaries between varieties create misleading identification of $F$. deltoidea varieties. The leaf characters are probably the most variable and showed heterophylly in the species [16]. Nevertheless, the young plant and the matured plant of the same 
variety often displayed different states of leaf characteristics. In this study, seven varieties collected from the Malay Peninsula of Malaysia, as mentioned by Kochummen [6], were selected, to investigate the monophyly of $F$. deltoidea and to differentiate intraspecific variation based on information contributed by overall morphological characters.

\section{Materials and Methods}

\section{Herbarium Specimens}

Morphological data were scored from 108 herbarium specimens, with prior permissions from four different herbaria; the Herbarium of the Universiti Kebangsaan Malaysia (UKMB), Herbarium of the Forest Research Institute of Malaysia (FRIM), Herbarium of Sarawak (SAN) and the National Herbarium of Singapore (SING). All measurements and observations were taken from the herbarium specimens except data for flowers, which were gathered from the literatures [2], [4-7], due to limited number of syconium presents on each herbarium sample.
2. Specific Taxa Analyzed (Relevant Herbarium Specimens Examined are Listed in Alphabetical Order by Locality, Collector Names and Numbers)

Ficus grossularioides Burm. f. (Selangor: Anuar 115670 UKMB); Ficus ischnopoda Miq. (Kelantan: Zainudin 5726 UKMB); Ficus oleifolia King (Sarawak: Jamre 70886 SAN); Ficus deltoidea var. angustifolia (Miq.) Corner (Kelantan: Khairudin 31953 FRIM, Latiff 1042, 1785 UKMB, Whitmore 4186 SING; Terengganu: Burkill 804 FRIM, Latiff 2772 UKMB, Lim 54622 FRIM, Shah 3823 FRIM, Shah 3313 SING; Pahang: Henderson 21994 SING, Shah 2694 SING, Syed 23374 SING, Whitmore 4824 FRIM, Zainudin 2001 UKMB, Zainudin 5199 UKMB; Penang: Ogata 13358 FRIM, Ng 27351 FRIM; Perak: Borges 3404 SING, Chan 17503 FRIM, Henderson 10239 SING, Ridley 3036 SING, Ridley 10235 SING; Selangor: Henderson 10489 SING, Hume 9937 SING, Nur 34359 FRIM, Symington 18164 FRIM, SING); F. deltoidea var. bilobata Corner (Kelantan: Whitmore 4258 SING; Pahang: Chew 868 FRIM, Henderson 11077 SING, Latiff 3131

Table 1. List of morphological characters and character states used in the phylogenetic analysis.

\begin{tabular}{|c|c|c|}
\hline No. & Characters & Character states \\
\hline 1 & Leaf length & 0 : more than $5 \mathrm{~cm}, 1$ : equal or less than $5 \mathrm{~cm}$. \\
\hline 2 & Leaf width & 0 : more than $5 \mathrm{~cm}, 1$ : equal or less than $5 \mathrm{~cm}$. \\
\hline 3 & Midrib & 0 : not forked to forked near the apex, 1 : forked near the middle of the lamina. \\
\hline 4 & Angle of the forked midrib & 0: not forked or forked less than 45 degrees, 1 : forked more than 45 degrees. \\
\hline 5 & Leaf apex & 0 : acute to acuminate, 1 : rounded to truncate and minutely emarginate to form bilobed. \\
\hline 6 & Leaf base & 0: obtuse, 1: acute. \\
\hline 7 & Leaf shape & 0: oblanceolate, 1: obovate, 2: spatulate. \\
\hline 8 & Leaf margin when dried & $0:$ serrate, 1 : entire, 2 : wavy. \\
\hline 9 & Leaf surface & 0 : veins deeply impressed, 1: plane or veins slightly impressed. \\
\hline 10 & Leaf venation & 0 : open venation, 1 : close venation. \\
\hline 11 & Waxy gland beneath the lamina & $0:$ two, 1 : equal or more than three. \\
\hline 12 & Gland at the forked midrib & 0 : absent, 1: present. \\
\hline 13 & \multicolumn{2}{|c|}{ Gland at the subsequent dichotomies of the midrib0: absent or rarely seen, 1 : commonly seen. } \\
\hline 14 & Petiole length & 0: more than $1.5 \mathrm{~cm}, 1$ : equal or less than $1.5 \mathrm{~cm}$. \\
\hline 15 & Petiole indument at tip & 0: puberulous, 1: glabrous. \\
\hline 16 & Stipule length & 0 : more than $0.5 \mathrm{~cm}, 1$ : equal or less than $0.5 \mathrm{~cm}$. \\
\hline 17 & Periderm persistent & 0 : present, 1: absent. \\
\hline 18 & Peduncle length & 0 : equal or less than $1 \mathrm{~cm}, 1:$ more than $1 \mathrm{~cm}$. \\
\hline 19 & Fig type & 0 : in pairs, 1 : solitary. \\
\hline 20 & Fig indumenta & 0: puberulous, 1: glabrous. \\
\hline 21 & Fig shape & 0: globose, 1: oblong. \\
\hline 22 & Fig length & 0 : equal or less than $1 \mathrm{~cm}, 1$ : more than $1 \mathrm{~cm}$. \\
\hline 23 & Fig width & 0 : more than $0.5 \mathrm{~cm}, 1$ : equal or less than $0.5 \mathrm{~cm}$. \\
\hline 24 & Fig base & 0 : cupulate, 1: cuneate. \\
\hline 25 & Fig apex & 0 : concave, 1: protracted. \\
\hline 26 & Ratio of fig length/width & $0:$ more than 1,1 : less than 1 \\
\hline 27 & Ostiole diameter & 0:1.5-2.5 mm, 1: less than $1.5 \mathrm{~mm}$. \\
\hline 28 & Color of ripening figs & 0 : yellow to orange to brownish red, 1 : rose red to dark purple. \\
\hline 29 & Tepals long over ovary & 0 : shorter than ovary, 1: as long as ovary, 2 : longer than ovary. \\
\hline 30 & Tepals color & 0 : red to dark purple, 1: yellowish red. \\
\hline 31 & Ovary shape & 0 : rugose-angular, 1: smooth or slightly angular. \\
\hline 32 & Ovary exocarp & 0: crustaceous, 1: fleshy. \\
\hline
\end{tabular}




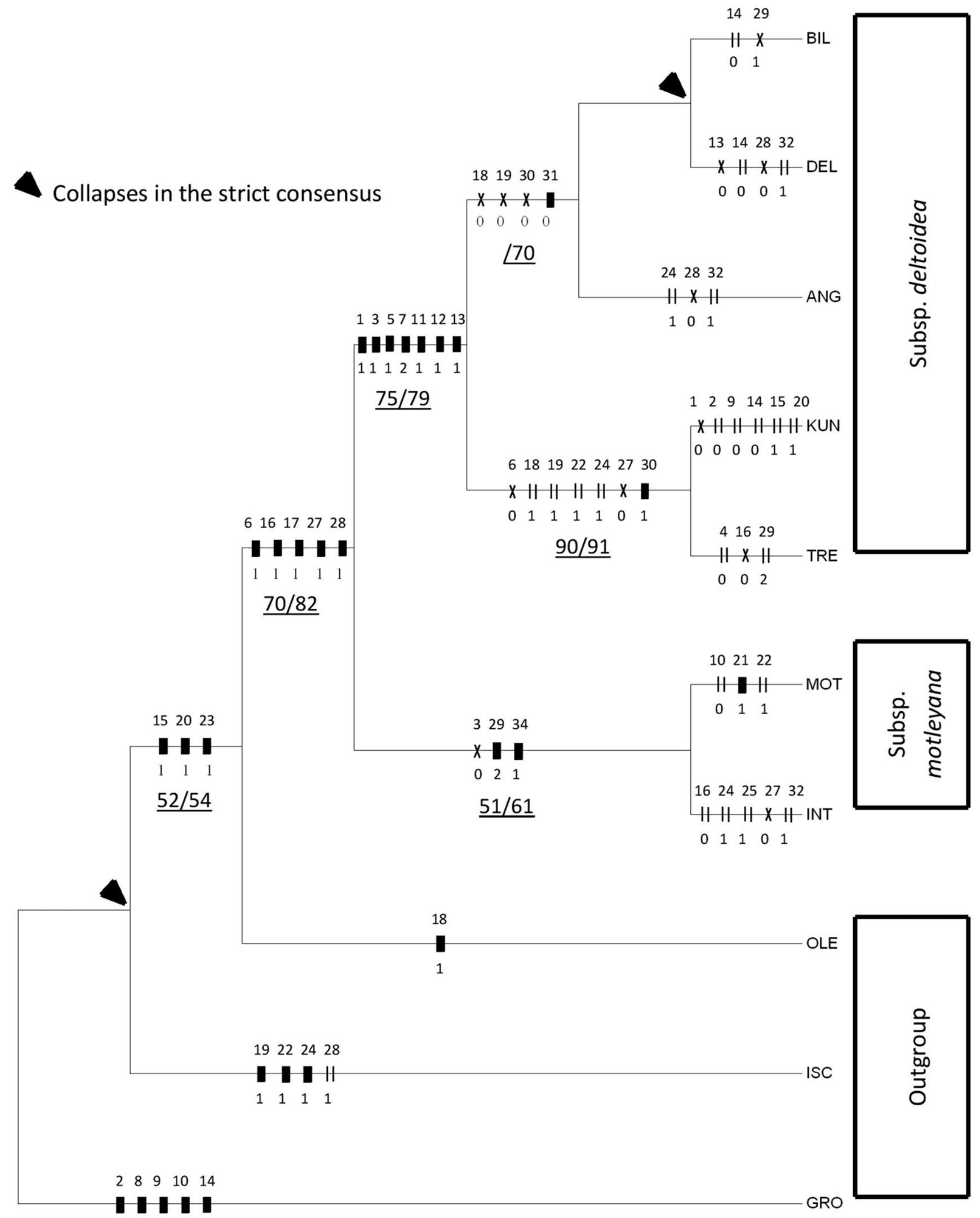

$\begin{array}{lllll}0 & 0 & 0 & 0 & 0\end{array}$

Figure 1. Neighbour-joining tree of $F$. deltoidea resulting from the morphological data. Terminal taxa: $G R O=F$. grossularioides, ISC $=F$. ischnopoda, $\mathrm{OLE}=$ F. oleifolia, $\mathrm{DEL}=$ var. deltoidea, $\mathrm{BIL}=$ var. bilobata, $\mathrm{ANG}=$ var. angustifolia, $\mathrm{KUN}=$ var. kunstleri, $\mathrm{TRE}=\mathrm{var}$. trengganuensis, $\mathrm{MOT}=\mathrm{var}$. 
motleyana, INT = var. intermedia. Bars = synaphomorphies; parallel lines = parallelisms; crosses = reversals. Underlined numbers below the branches are bootstrap percentage value of maximum parsimony/neighbour-joining analyses.

doi:10.1371/journal.pone.0052441.g001

UKMB, Latiff 4085 UKMB, FRIM, Shah 2694 FRIM, Zainudin 4636 UKMB, FRIM; Perak: Nauen 1099 SING); F. deltoidea var. deltoidea Corner (Johor: Arishah 66 UKMB, Asiah 57 UKMB, Corner 32250 SING, Latiff 144, 698 UKMB, Mat 154 SING, Rahim 28 UKMB, Saidah 15 UKMB, Shafee 46 UKMB, Tan 102 FRIM, Teruya 434 SING, Zainal 20 UKMB; Kedah: Zainudin 3981 UKMB; Negeri Sembilan: Rasidah 023 UKMB, Satariah 52 UKMB; Pahang: Allen 111 SING, Zainudin 2336 UKMB); F. deltoidea var. trengganuensis Corner (Kelantan: Whitmore 4258 FRIM; Terengganu: Henderson 31039 FRIM, Kamarudin 219 UKMB, Kasim 1626 UKMB, Moysey 31075 FRIM, Rozi 67 UKMB, Sani 712 UKMB, Shah 4035 FRIM, Whitmore 12675 FRIM, Zainudin 3008 UKMB; Pahang: Ogata 10437 FRIM, Ridley 439 SING, Samsuri 464 FRIM, Yeoh 3112 SING). F. deltoidea var. intermedia Corner (Pahang: Asiah 086 UKMB, Asmah 72 UKMB, Henderson 23589 SING, Kasim 968 UKMB, Kiew 3823 SING, Littke 547 UKMB, Noraini 052 UKMB, Ridley 13717 SING, Rohani 068 UKMB, Saudah 056 UKMB, Shah 654 SING, Shah 2984 SING, Zainudin 1433 UKMB; Perak: Henderson 11818 SING). F. deltoidea var. kunstleri (King) Corner (Kelantan: Haniff 10230 SING, Henderson 29645 SING, Latiff 1041, 1899 UKMB; Pahang: Latiff 78 UKMB, Shah 1804 FRIM, Whitmore 3548 FRIM, Whitmore 3548 SING, Zainudin 17894 SING; Perak: Foston 45196 FRIM, Chelliah 98602 SING, Sanisah 1018 FRIM; Selangor: Mead 30761 FRIM); F. deltoidea var. motleyana (Miq.) C. C. Berg (Kelantan: Whitmore 20650 FRIM; Terengganu: Mahmud 4930 FRIM, Shah 4930 SING; Pahang: Ng 9726 FRIM, Symington 28908 SING, Whitmore 3227, 4848 FRIM).

\section{Characters}

The characters were surveyed throughout the ingroup and outgroup taxa using criteria of putative homology or hypothetical homology [17]. Furthermore, the characters should consistent in occurrence or absence among the terminal taxa, which implies that they are not environmentally plastic [18]. As a basic principle, the characters that varied between terminal taxa were chosen, but not those that varied within the taxa. In total, 32 morphological characters including 29 binary and three multistate characters were prepared (Table 1). Character states were then polarized using outgroup comparison method [19]. If a character state was not available or not applicable in a taxa, it was designated as missing.

\section{Phylogenetic Analyses}

The phylogenetic analyses were performed using the maximum parsimony (MP) and Wagner approaches and trees were generated using the PAUP* version 4.0b10 software [20,21]. All character states were run as unordered with equal weight. The search for the most parsimonious tree was determined by exhaustive search and bisection-reconnection (TBR) branch swapping, with retention of multiple parsimonious trees (MaxTrees $=100$ ). Branches were collapsed and polytomies were created when maximum branch length is zero. Optimization of characters was performed using the ACCTRAN (Accelerated Transformation Optimization) option. To test the support for each clade, bootstrap analysis [21] was performed with 1000 replicates of simple taxon addition and TBR swapping, with a limit of 10 trees kept per replicate. Bootstrap percentages (BS) of 50-70 was considered weak, 71-85 as moderate and $>85$ as strong [22]. The distance tree was estimated by the neighbour-joining (NJ) method [23] based on the formulae of Kimura [24]. Graphic outputs were produced using the TreeView X software [25] and characters were mapped onto a single tree [26].

\section{Results}

The resultant data matrix is shown in Table S1. The analysis of the data matrix, containing nine terminal taxa and 32 characters, produced two shortest maximum parsimony (MP) trees with a minimum length of 68 steps, a consistency index (CI) of 0.5147 and a retention index (RI) of 0.5976 . A total of 31 parsimonyinformative characters and only one parsimony-uninformative character were found in the dataset. The only difference between the two trees topologies is the position of var. motleyana and var. intermedia, which was supported and characterized by tepals longer than ovary (\#29) and a synapomorphy of smooth and slightly angular ovary (\#31). There was no character found to support this group, thus collapsed into polytomy in the other tree. Other character transformation series within the whole tree were found to be almost identical in both trees. The results were then compared with the neighbour-joining (NJ) tree (Figure 1). Noted that the topology was similar in $\mathrm{MP}$ and $\mathrm{NJ}$ trees, but the bootstrap supports (BS) of NJ tree were generally improved compared to the MP tree.

Ficus deltoidea formed a weakly-moderately supported clade with bootstrap support of $70 \%$ and $82 \%$ in the MP and NJ trees, respectively. The group was characterized by the important characters of leaf base acute (\#6), stipule length equal or less than $0.5 \mathrm{~cm}(\# 16)$, periderm not persistent (\#17), ostiole diameter less than $1.5 \mathrm{~mm}$ (\#27) and color of ripening fig that is rose red to dark purple (\#28). The species was divided into two clades; clade subspecies deltoidea (BS $=75 \% / 79 \%$ ) and clade subspecies motleyana (BS $=51 \% / 61 \%$ ), of which the first clade comprised of five varieties namely, var. angustifolia, var. bilobata, var. deltoidea, var. kunsleri and var. trengganuensis, whereas the second clade contained two varieties namely, var. intermedia and var. motleyana.

The placement of clade subspecies deltoidea was moderately supported with $75 \%$ and $79 \%$ bootstrap values in the MP and NJ analyses, respectively. It was defined by the following characters; leaf length equal or less than $5 \mathrm{~cm}(\# 1)$, midrib forked near the middle of the lamina (\#3), leaf apex rounded to truncate and minutely emarginate to form bilobed (\#5), leaf spatulate (\#7), waxy gland beneath the lamina is equal or more than three (\#11), gland present at the forked midrib (\#12) and commonly seen at the subsequent dichotomies of the midrib (\#13). Within subspecies deltoidea, var. kunsleri and var. trengganuensis formed a strongly supported clade, $90 \%$ and $91 \%$ in the MP and NJ trees, respectively. They were described by having obtuse leaf base (\#6), peduncle length more than $1 \mathrm{~cm}(\# 18)$, fig borne in pairs (\#19), fig length more than $1 \mathrm{~cm}$ (\#22), fig cuneate at the base (\#24), ostiole diameter between 1.5-2.5 mm (\#27) and flowers with yellowish-red tepals (\#30). However, var. kunstleri was discriminated from its ally by having leaf length and width that is more than $5 \mathrm{~cm}$ each (\#1), (\#2), veins are deeply impressed (\#9), petiole length more than $1.5 \mathrm{~cm}(\# 14)$, glabrous at the tip (\#15) and glabrous fig (\#20), whereas var. trengganuensis was identified by having midrib forked less than 45 degrees (\#4), stipule length more than $0.5 \mathrm{~cm}$ (\#16) and tepals longer than ovary (\#29). The positions of var. deltoidea, var. bilobata and var. 
Table 2. Fluctuation of taxonomic rank in F. deltoidea based on geographic regions.

\begin{tabular}{|c|c|c|c|c|c|c|}
\hline Author & Corner (1960) & Corner (1969) & Kochummen (1978) & Kochummen (1998) & $\begin{array}{l}\text { Kamarudin and } \\
\text { Latiff }(2002)\end{array}$ & $\begin{array}{l}\text { Berg (2003); Berg and } \\
\text { Corner (2005) }\end{array}$ \\
\hline \multirow{9}{*}{$\begin{array}{l}\text { Geographic } \\
\text { Regions }\end{array}$} & South East Asia & South East Asia & Peninsular Malaysia & Malaysia and Borneo & Malaysia & Malesia \\
\hline & - & - & - & - & - & $\begin{array}{l}\text { A) Subspecies } \\
\text { deltoidea }\end{array}$ \\
\hline & v. angustifolia & v. angustifolia & v. angustifolia & v. angustifolia & v. angustifolia & v. angustifolia \\
\hline & f. angustissima & f. angustissima & - & - & - & f. angustissima \\
\hline & v. arenaria & v. arenaria & - & - & - & v. arenaria \\
\hline & v. bilobata & v. bilobata & v. bilobata & v. bilobata & v. bilobata & v. bilobata \\
\hline & v. borneensis & v. borneensis & - & - & - & v. borneensis \\
\hline & f. subhirsuta & f. subhirsuta & - & v. subhirsuta & - & f. subhirsuta \\
\hline & v. intermedia & v. intermedia & v. intermedia & v. intermedia & v. intermedia & \\
\hline \multirow[t]{12}{*}{ Taxa } & v. kunstleri & v. kunstleri & v. kunstleri & v. kunstleri & v. kunstleri & v. kunstleri \\
\hline & v. lutescens & v. lutescens & - & - & - & v. lutescens \\
\hline & f. longipedunculata & f. longipedunculata & - & - & - & f. longipedunculata \\
\hline & f. subsessilis & f. subsessilis & - & - & - & f. subsessilis \\
\hline & v. peltata & v. peltata & - & - & - & v. peltata \\
\hline & v. trengganuensis & v. trengganuensis & v. trengganuensis & v. trengganuensis & v. trengganuensis & v. trengganuensis \\
\hline & v. deltoidea & v. deltoidea & v. deltoidea & v. deltoidea & - & \\
\hline & - & v. kinabaluensis & - & - & - & \\
\hline & - & - & - & v. recurvata & - & v. recurvata \\
\hline & - & - & - & - & - & $\begin{array}{l}\text { B) Subspecies } \\
\text { motleyana }\end{array}$ \\
\hline & v. motleyana & v. motleyana & v. motleyana & v. motleyana & v. motleyana & v. motleyana \\
\hline & v. oligoneura & v. oligoneura & - & - & - & v. oligoneura \\
\hline
\end{tabular}

angustifolia were defined by extremely low confidence in the MP analysis and therefore, relationship between these varieties were not certain. However, the NJ analysis support their relationship by $70 \%$ bootstrap support and they share the peduncle length that is equal or less than $1 \mathrm{~cm}(\# 18)$, fig solitary (\#19), flowers with red and dark purple tepals (\#30) and rugose-angular ovary (\#31). Within this group, var. angustifolia was identified by having fig cuneate at the base (\#24), ripening fig yellow to orange to brownish red (\#28) and ovary with fleshy exocarp (\#32), whilst var. bilobata showed a unique autapomorphy of tepals length that is as long as ovary (\#29).

The clade subspecies motleyana received weak bootstrap support of $51 \%$ in the MP analysis, but was moderately supported, $61 \%$ in the $\mathrm{NJ}$ analysis. It was distant to subspecies deltoidea by having midrib not forked to forked near the apex (\#3), tepals longer than ovary (\#29) and smooth or slightly angular ovary (\#31). Within subspecies motleyana, var. intermedia was distinguished by having stipule length more than $0.5 \mathrm{~cm}$ (\#16), fig cuneate at the base (\#24), protracted at the apex (\#25), ostiole diameter between 1.5$2.5 \mathrm{~mm}$ (\#27) and ovary with fleshy exocarp (\#32). On the other hand, var. motleyana showed an autapomorphy of fig oblong in shape (\#21).

\section{Discussion}

Most of the previous classifications (Table 2) were based on intuitive morphology. The number of varieties was easily increased or reduced based on its morphological variation and locality [27]. Different authors had their own opinion in discriminating taxon, such as Corner [28] who divided the South East Asian species of $F$. deltoidea into twelve varieties and four forma, namely, var. deltoidea, var. angustifolia f. angustissima Corner, var. arenaria Corner, var. bilobata, var. borneensis Corner f. subhirsuta Corner, var. intermedia, var. kunstleri, var. lutescens (Desf.) Corner f. longipedunculata Corner, f. subsessilis (Miq.) Corner, var. motleyana, var. oligoneura (Miq.) Corner, var. peltata Corner and var. trengganuensis. Later, he introduced a new variety, var. kinabaluensis Stapf which probably is a synonym of var. intermedia of Borneo with larger peduncle and leaves [4]. On the other hand, Kochummen [4] has divided $F$. deltoidea into seven varieties namely, var. deltoidea, var. bilobata, var. angustifolia, var. intermedia, var. kunstleri, var. motleyana and var. trengganuensis, which were available in the Malay Peninsula of Malaysia or formerly known as Malaya, and described them. Later on, two endemic varieties of Borneo, namely var. subhirsuta Kochummen and var. recurvata Kochummen were added [27]. Berg [2] and Berg and Corner [7] recently subdivided the species into two major morphological entities (subspecies deltoidea and subspecies motleyana) which seems to be more practical and satisfactory in handling the variation. They further mentioned that as strong phytogeographical and ecological support is lacking, the rank of variety proposed by others might be more correct, but the chosen rank allows recognition of varieties for regional use. Therefore, the sampling of this study focused on the earlier classification scheme of Kochummen [6] who studied seven varieties from Peninsular Malaysia 
region. These varietal variations then might be useful for allocating plant material to varieties as required for therapeutic and pharmaceutical applications.

In this study, Ficus deltoidea formed one major clade. Nevertheless, character variation in the dataset was insufficient to resolve all the phylogenetic relationships, especially among the internal branching of subspecies deltoidea. The divergence of var. deltoidea, var. angustifolia and var. bilobata received extremely low bootstrap support, thus the branches collapsed in the strict consensus tree. The placement of these varieties, as revealed by a previously published RAPD analysis, were also uncertain due to the variable banding patterns and hence showed that similar varieties were grouped into different clusters [9].

From the results obtained, the seven varieties of $F$. deltoidea of Malesian region can be placed into two subspecies: subspecies deltoidea consisted of var. deltoidea, var. bilobata, var. angustifolia, var. kunstleri and var. trengganuensis. Within the subspecies deltoidea, var. kunstleri was shown to be more closely related to var. trengganuensis than to the other varieties. The positions of var. deltoidea, var. bilobata and var. angustifolia received extremely low support in the MP tree, suggesting that the analysis did not assure the relationships between these varieties. However, they were genetically closely related to each other and were fairly supported in the NJ analysis. This should, however, be confirmed by a detailed molecular studies. The second, subspecies motleyana comprised var. intermedia and var. motleyana. Our results showed an agreement with Berg [2], and Berg and Corner [7] that proposed the two subspecies based on the forked and non-forked midrib. Noted that var. intermedia was excluded in their classifications and then was transferred to $F$. oleifolia subspecies intermedia, because of mixture in characters of forked and non-forked midrib, and leaf shapes ranging from spatulate to obovate to oblanceolate [2,7]. However, this study showed that the relationship between var. intermedia and var. motleyana was constantly supported and defined in both the $\mathrm{MP}$ and NJ analyses.

With respect to intergeneric relationship between $F$. deltoidea, F. ischnopoda Miq., F. oleifolia King and F. grossularioides Burm.f., $F$. oleifolia was found to be the closest ally to $F$. deltoidea, whilst $F$. ischnopoda and $F$. grossularioides were placed at the base of trees and did not get any bootstrap support (Figure 1). Their relationships, however, continue to require explicit examination using a combination of molecular and developmental dataset. It is

\section{References}

1. Sata T (1944) A monographic study of the genus Ficus from the point of view of economic botany. Contr Hort Inst Taihoku Imp Univ 32: 1-405.

2. Berg CC (2003) Flora Malesiana precursor for the treatment of Moraceae 3: Ficus subgenus Ficus. Blumea 48: 529-550.

3. USDA (2007) ARS, National genetic resources program, Germplasm resources information network-(GRIN) database (National germplasm resources laboratory, Beltsville, Maryland) [online]. Available: http://ars-grin.gov/cgi-bin/ npgs/html/taxon.pl?16826. Accessed 2010 June 14

4. Corner EJH (1969) The complex of Ficus deltoidea; a recent invasion of the Sunda Shelf. Philosophical Transactions of the Royal Society of London 256: 281-317.

5. Musa Y (2005) Variability in morphology and agronomy of emas cotek accessions found in Kelantan and Terengganu. Buletin Teknol Tanaman 2: 3548.

6. Kochummen KM (1978) Moraceae. In: Ng FSP (ed) Tree flora of Malaya (A manual of foresters) volume three. Malaysia, Longman Malaysia Sdn. Bhd.pp. $119-168$.

7. Berg CC, Corner EJH (2005) Flora Malesiana Series I - seed plants: Moraceaea - Ficus. Volume 17 Part 2. Foundation Flora Malesiana.

8. Kamarudin MS, Latiff AM (2002) Tumbuhan ubatan Malaysia. Percetakan Watan Sdn. Bhd., Malaysia (in Bahasa Melayu).

9. Subhash JB, Nurul AH, Farida HS (2009) Genetic variability based on random amplified polymorphic DNA in mistletoe fig (Ficus deltoidea Jack) collected from Peninsular Malaysia. J For Sci 25: 57-65. interesting to note that Rønsted et al., [29] groups $F$. deltoidea var. borneensis and $F$. oleifolia together with $F$. adenosperma Miq., $F$. ochrochlora Ridl., F. dammaropsis Diels, F. pumila L., F. erecta Thunb., and placed $F$. ischnopoda at the base of section Ficus/Adenosperma on the basis of several molecular datasets. Furthermore, Rønsted et al., [30] recently found that $F$. oleifolia and $F$. ischnopoda were the closer relatives to $F$. deltoidea var. borneensis in subsection Frutescentiae, whilst $F$. grossularioides more remotely in section Eriosycea. The sampling of subsection Frutescentiae and F. deltoidea varieties has been very limited in the previous phylogenetic studies, which makes it difficult to know what would be the close relatives and appropriate outgroup. Therefore, it is not possible at this stage to compared $F$. deltoidea to its allies because there is no comprehensive phylogenetic classification available for comparison.

This study was the first attempt to suggest a morphological phylogenetic framework for the seven varieties of Ficus deltoidea from the Malay Peninsular, which will provide a basis for future molecular, cytological or phytochemical as well as pharmaceutical investigations. Deeper understanding of the systematic relationships between the varieties will help to promote expeditious exploitation and sustainable uses of this plant as a whole.

\section{Supporting Information}

Table S1 Data matrix for 32 morphological characters. "0" represents the plesiomorphic state, and " 1 " or " 2 " represents the apormorphic state. Missing data are indicated by "?".

(DOC)

\section{Acknowledgments}

The authors would like to express special thanks to the Herbarium of the Universiti Kebangsaan Malaysia (UKMB), Herbarium of the Forest Research Institute of Malaysia (FRIM), Herbarium of Sarawak (SAN) and the National Herbarium of Singapore (SING) for the loans of their herbarium specimens.

\section{Author Contributions}

Conceived and designed the experiments: AMA NM AYG HNNF. Performed the experiments: HNNF ARNZ MNZ HH. Analyzed the data: HNNF MNZ MK. Contributed reagents/materials/analysis tools: NM AMA. Wrote the paper: HNNF NM AMA.

10. Sulaiman MR, Hussain MK, Zakaria ZA, Somchit MN, Moin S, et al (2008) Evaluation of the antinociceptive activity of Ficus deltoidea aqueous extract. Fitoter 79: $557-561$.

11. Omar MH, Mullen W, Crozier A (2011) Identification dimmers and trimers, flavone C-glycosides, and antioxidant in Ficus deltoidea, a Malaysian herbal tea. J. Agric \& Food Chem 59: 1363-1369.

12. Norhaniza A, Sin CY, Chee ES, Nee KI, Renxin L (2007) Blood glucose lowering effect of Ficus deltoidea aqueous extract. Malays J Sci 26: 73-78.

13. Adam Z, Ismail A, Khamis S, Mokhtar MHM, Hamid M (2011) Antihyperglycemic activity of $F$. deltoidea ethanolic extract in normal rats. Sains Malaysiana 40: 5489-5495.

14. Farsi E, Shafaei A, Hor SY, Ahamed MBK, Yam MF, et al (2011) Correlation between enzymes inhibitory effects and antioxidant activities of standardized fractions of methanolic extract obtained from Ficus deltoidea leaves. African J Biotech 10: 15184-15194.

15. Bailey LH, Bailey EZ (1976) Hortus. 3rd ed. Macmillan General Reference, New York.

16. Nashriyah M, Nurrul Akmar R, Nor Zaimah AR, Norhaslinda H, Zanariah MN, et al (2012) Leaf morphological variations and heterophylly in Ficus deltoidea Jack (Moraceae). Sains Malaysiana 41: 527-538.

17. Fatihah NHN, Maxted N, Arce LR (2012) Cladistic analysis of Psophocarpus Neck. ex DC. (Leguminosae, Papilionoideae) based on morphological characters. S Afr J Bot. 83, 78-88.

18. Pennington RT (1996) Molecular and morphological data provide phylogenetic resolution at different hierarchical levels in Andira. Syst Biol 45: 496-515. 
19. Watrous LE, Wheeler QD (1981) The out-group comparison method of character analysis. Syst Zool 30: 1-11.

20. Swofford DL (2002) PAUP*. Phylogenetic analysis using parsimony (*and other methods), Version 4. Sinauer Associates, Sunderland, Massachusetts.

21. Felsenstein J (1985) Confidence limit on phylogenies: an approach using the bootstrap. Evol 39: 783-791.

22. Kress WJ, Prince LM, William KJ (2002) The phylogeny and a new classification of the gingers (Zingiberaceae): evidence from molecular data. Am J Bot 89: $1682-1696$.

23. Satou N, Nei M (1987) The neighbour-joining method: a new method for reconstructing phylogenetic trees. Mol Biol Evol 4: 406-425.

24. Kimura M (1980) A simple method for estimating evolutionary rate of base substitution through comparative studies of nucleotide sequences. J Mol Evol 16: $111-120$.
25. Page RDM (1996) TREEVIEW: an application to display phylogenetic trees on personal computers. Comput Appl Biosci 12: 357-358.

26. Hoberg EP, Jones A, Bray RA (1999) Phylogenetic analysis among the families of the Cyclophyllidea (Eucestoda) based on comparative morphology, with new hypotheses for co-evolution in vertebrates. Syst Parasitol 42: 51-73.

27. Kochummen KM (1998) New species and varieties of Moraceae from Malaysia. Garden's Bulletin Singapore 50: 197-219.

28. Corner EJH (1960) Taxonomic notes on Ficus Linn., Asia and Australasia. III. Subgen. Ficus and section Ficus. Garden's Bulletin Singapore 17: 416-441.

29. Rønsted N, Weiblen GD, Cook JM, Salamin N, Machado CA, et al (2005) 60 million years of co-divergence in the fig-wasp symbiosis. Proc R Soc B 272: 2593-2599.

30. Rønsted N, Weiblen GD, Clement W, Zerega N, Savolainen V (2008) Reconstructing the phylogeny of figs (Ficus, Moraceae) to unravel the origin of fig-wasp mutualisms. Symbiosis 45: 45-56. 